\title{
The growth performance and meat quality of goats fed diets based on maize or wheat grain*
}

\author{
Y. Yang ${ }^{1}$, X.M. Li ${ }^{1}$, Z.H. Sun ${ }^{1,5}$, T. Yang ${ }^{1}$, Z.L. Tan ${ }^{2}$, B.F. Wang ${ }^{3}$, \\ X.F. $\mathrm{Han}^{2}$ and Z.X. $\mathrm{He}^{2}$
}

${ }^{1}$ Key Laboratory of Bio-feed and Animal Nutrition, College of Animal Science and Technology, Southwest University Chongqing 400715, P.R. China

${ }^{2}$ Key Laboratory of Agro-ecological Processes in Subtropical Region, Institute of Subtropical Agriculture, the Chinese Academy of Sciences

Changsha 410125, P.R. China

${ }^{3}$ Liuyang Black Goat Reproduction Center

Liuyang 410300, P.R. China

(Received 24 November 2011; revised version 2 October 2012; accepted 15 November 2012)

\begin{abstract}
A total of 24 four-month-old Liuyang Black wether goats $(10 \pm 0.2 \mathrm{~kg})$ were allotted to two diets based on wheat and maize to investigate effects of starch sources on the growth performance and meat quality. The experimental period lasted for 100 days, including 10 days for adaptation. Five representative goats from each group were selected for slaughter on the last experimental day. The final body weight and body weight gain of goats in wheat group were lower than those of goats in maize group $(\mathrm{P}<0.05)$, however, the marbling score of the Longissimus dorsi of goats in wheat group was greater than that of goats in maize group $(\mathrm{P}<0.05)$. Fatty acid composition of Longissimus dorsi muscle was also different between wheat group and maize group, for example, the proportion of C14:0 in Longissimus dorsi muscle of goats in wheat group was greater than that of goats in maize group ( $\mathrm{P}<0.05)$, and the proportion of $\mathrm{C} 18: 3$ in Longissimus dorsi muscle of goats in wheat group was smaller than that of goats in maize group. Results indicate that growth performance of the goats
\end{abstract}

\footnotetext{
* Supported the Key Projects in the National Science \& Technology Pillar Programme, 2012BAD 14B18 and 2011BAD36B01; National Program on Key Basic Research Project of China, 2013CB127300; the Fundamental Research Funds for the Central Universities, XDJK2011B011; Doctoral Fund of Southwest University (The Program of Talent Introduction, No. SWU110054); the National Natural Science Foundation of China, No. 30600436; and the Key Technologies R \& D Program of Changsha City, K1101189-21

${ }^{5}$ Corresponding author: e-mail: sunzh2002cn@yahoo.com.cn
} 
fed the diet based on maize was better and the proportion of 18:3 fatty acids and marbling score of Longissimus dorsi muscle was smaller in comparison with the goats fed the diet based on wheat.

KEY WORDS: goat, meat quality, starch sources, growth performance, diet

\section{INTRODUCTION}

It is well known that seed structure and chemical composition vary among plant species, and among varieties within species. Starch granules within a seed vary in size, amorphous or crystalline structure, and type of polysaccharide, amylose, or amylopectin (Svihus et al., 2005). The differences in structure and chemical composition would cause different ruminal degradation characteristics of nutrients among plant species, and among varieties within species. The starch from maize and wheat are fermented in different ways in the rumen, the soluble starch (\% total starch) of maize and wheat was $26 \%$ and $68 \%$, and the potentially degradable starch (\% total starch) of maize and wheat was $64 \%$ and $32 \%$ in the rumen, respectively (Mills et al., 1999). The soluble nitrogen $(\mathrm{N})$ (\% crude protein, CP) was $28 \%$ and $27 \%$, and the potentially degradable $\mathrm{N}(\% \mathrm{CP})$ was $65 \%$ and $71 \%$ for maize and wheat in the rumen, respectively (NRC, 2001). Obviously, the degradation characteristics of starch and $\mathrm{N}$ in the rumen differ between wheat and maize.

The degradability and digestibility of dietary starch in the rumen influence not only the extent of microbial fermentation and protein synthesis in the rumen (Ørskov, 1975; Hoover and Stokes, 1991), but also the availability of nutrients in the post ruminal digestive tract (Taniguchi et al., 1995), whole-body nitrogen metabolism and milk yield and composition in ruminant (Khan et al., 2007). The portal-drained viscera (PDV) net fluxes of total free amino acids, glycine, isoleucine, leucine, phenylalanine, proline, serine, threonine, tryptophan and valine were greater in cows fed steam-flaked maize than those of cows fed steam-rolled maize (Tagari et al., 2004). The differences in PDV net fluxes of amino acids of diets based on the various starch sources may be one of main reasons for the differences in wholebody nitrogen metabolism and milk yield and composition in ruminants.

Nutritional factors have significant influences on the growth performance, structural and biochemical characteristics of carcass and on meat quality traits (Szabó et al., 2001). Previous studies have demonstrated energy is the key factor for carcass and meat quality traits of meat ruminants (McEwen et al., 2007; Rhoades et al., 2007; Huuskonen, 2009). Ørskov et al. (1974 a,b) found the differences in growth performance and the carcass fatty acid composition of lambs fed diets based on maize and wheat. Hereafter, scientific researches to evaluate the differences in growth performance and meat quality of meat ruminants fed diets based on different starch sources, especially on maize and wheat, are few. 
We found that the goats fed the diet based on maize was associated with higher net fluxes of lysine, methionine and valine across the portal drained viscera (PDV), and lower urea-N concentration in the portal vein and net PDV flux of ammonia-N when compared with the goats fed the diet based wheat (Sun et al., 2011). On the basis of the above-mentioned study, the present study was carried out to investigate the growth performance and meat quality of goats fed the diets based on maize and wheat.

\section{MATERIAL AND METHODS}

\section{Animals and management}

The use of animals and the procedure of the experimentation with animals were in accordance to the Animal Care and Guidelines of Chinese Southwest University.

The 4-month-old Liuyang Black goats were obtained from Liuyang Black Goat Reproduction Center, Liuyang city, Hunan province (China). A total of 24 castrated male goats $(10 \pm 0.2 \mathrm{~kg})$ were involved in the present experiment. The goats were randomly divided into two groups, and assigned to two diets (Table 1).

Table 1. Ingredients and nutrient composition of experimental diets, \% DM basis ${ }^{1}$

\begin{tabular}{|c|c|c|}
\hline \multirow{2}{*}{ Indices } & \multicolumn{2}{|c|}{ Starch sources } \\
\hline & wheat & maize \\
\hline \multicolumn{3}{|l|}{ Ingredients, \% } \\
\hline maize stover & 60 & 60 \\
\hline maize & - & 25 \\
\hline wheat & 25 & - \\
\hline soyabean meal & 10 & 11 \\
\hline rice bran & 3 & 0 \\
\hline fish meal & 0 & 2 \\
\hline $\mathrm{NaCl}$ & 1 & 1 \\
\hline premix $^{2}$ & 1 & 1 \\
\hline \multicolumn{3}{|c|}{ Nutrient composition } \\
\hline $\mathrm{ME}^{3}, \mathrm{MJ} \mathrm{kg}^{-1}$ & 9.90 & 10.2 \\
\hline crude protein & 13.0 & 12.8 \\
\hline starch & 15.0 & 14.9 \\
\hline NDF & 40.5 & 40.2 \\
\hline $\mathrm{CA}_{\mathrm{A}}$ & 0.68 & 0.65 \\
\hline $\mathrm{P}$ & 0.29 & 0.28 \\
\hline \multicolumn{3}{|c|}{$\begin{array}{l}{ }^{1} \text { values, expressed on a DM basis, are the average of duplicates; }{ }^{2} \text { premix contained per kg: g: } \\
\mathrm{MgSO}_{4} \cdot \mathrm{H}_{2} \mathrm{O} 119, \mathrm{FeSO}_{4} \cdot 7 \mathrm{H}_{2} \mathrm{O} 2.5, \mathrm{CuSO}_{4} \cdot 5 \mathrm{H}_{2} \mathrm{O} 0.8, \mathrm{MnSO}_{4} \cdot \mathrm{H}_{2} \mathrm{O} 3, \mathrm{ZnSO}_{4} \cdot \mathrm{H}_{2} \mathrm{O} \text { 5; mg: } \\
\mathrm{Na}_{2} \mathrm{SeO}_{3} 10, \mathrm{KI} 40, \mathrm{CoCl}_{2} \cdot 6 \mathrm{H}_{2} \mathrm{O} 30 \text {; IU: vit. } \mathrm{A} 95.000 \text {, vit. } \mathrm{D} 17.500, \text { vit. } \mathrm{E} 18.000 \\
{ }^{3} \text { metabolizable energy values were as reported by Zhang and Zhang (1998), the others were } \\
\text { determined values }\end{array}$} \\
\hline
\end{tabular}


The amounts of the feeds offered to goats were controlled to provide nutrition at a plane of approximately 1.3 times the metabolizable energy requirement for maintenance (Lu et al., 1996). Both the concentrate and maize stover were fed separately, and the daily supply of feed was divided into two equal portions fed at 08.00 and $18.00 \mathrm{~h}$ during the entire experimental period. The experiment lasted 100 days, including 10 days for adaptation.

\section{Sampling and measurements}

Samples of feeds (concentrates and maize stover) were taken daily, pooled and sub-samples were taken. The feed refusals were collected daily, weighed, pooled, and sub-samples were stored at $4^{\circ} \mathrm{C}$ for later analysis. The initial body weight (the body weight of goats after adaptation) and final body weight were recorded to calculate body weight gain.

The goats were slaughtered at the last experimental day after a 12-h fasting period, and hot carcass weight was recorded. After removing the skin, instrumental colour CIE L* (lightness), a* (redness) and b* (yellowness) (CIE, 1986) readings were taken in Rectus abdominis muscle using a MIMOLAT CM 2002 colorimeter (illuminant: D65; visual angle: $10^{\circ}$ ). Carcass fat colour was also measured at caudal level according to the colour system described above. Carcasses were subsequently ribbed between the $12^{\text {th }}$ and $13^{\text {th }}$ ribs. Longissimus dorsi area was traced upon acetate paper and measured with a compensating planimeter (Burke and Apple, 2007). The $\mathrm{pH}$ value of the Longissimus dorsi between the $10^{\text {th }}$ and $11^{\text {th }}$ rib from the right side was measured using a $\mathrm{pH}$ meter equipped with a penetrating glass electrode at $40 \mathrm{~min}$ post-mortem. After finishing the above analysis, the Longissimus dorsi at the right side was collected and then stored at $4{ }^{\circ} \mathrm{C}$. At $24 \mathrm{~h}$ post-mortem, the $\mathrm{pH}$ value of the Longissimus dorsi at the same position was determined. After finishing $\mathrm{pH}$ determination, the samples of Longissimus dorsi were vacuum-packed and frozen at $-20^{\circ} \mathrm{C}$ for later analysis of moisture, crude fat, ash, and intramuscular fatty acid composition.

\section{Analytical procedures}

Moisture, crude fat and protein of the Longissimus dorsi between the $5^{\text {th }}$ and $7^{\text {th }}$ rib junction were assessed according to AOAC (1995) procedures, after $24 \mathrm{~h}$ thawing at $4^{\circ} \mathrm{C}$. Ash was analysed by burning oven-dried samples in a muffle furnace at $550^{\circ} \mathrm{C}$ according to ISO 5984 (1978).

Fatty acid profiles of the Longissimus dorsi between the $9^{\text {th }}$ and $11^{\text {th }}$ rib junction was determined with gas chromatography (Wiegand et al., 2002). Firstly, lipids were extracted from the respective liquid nitrogen pulverized samples using the 
Folch extraction method (Folch et al., 1957). Fatty acid methyl esters (FAME) were prepared for gas chromatography determination using sodium methoxide ( $\mathrm{Li}$ and Watkins, 1998). One $\mathrm{ml}$ of hexane was added to each of the scintillation vials from the Folch extraction, and $2 \mathrm{ml}$ of sodium methoxide was added to each vial, and the vials were vortexed at low speed for $30 \mathrm{~s}$. Vials were incubated in a heat block at $50^{\circ} \mathrm{C}$ for $10 \mathrm{~min}$, and $5 \mathrm{ml}$ of deionized water and $0.1 \mathrm{ml}$ of glacial acetic acid were added to each vial. Lipids were extracted with two successive washings of $3 \mathrm{ml}$ of hexane per vial, and $0.5 \mathrm{~g}$ of anhydrous sodium sulphate was added to each vial to remove any residual water. One $\mathrm{ml}$ of the FAME was transferred to a gas chromatography vial and stored at $4^{\circ} \mathrm{C}$ until analysis. All FAME was analysed with a gas chromatography system (G-3000, Tokyo, Japan). The apparatus was equipped with a flame ionization detector and fitted with a $0.3 \mathrm{~mm} \times 30 \mathrm{~m}$ glass column packed with DB-wax. The carrier gas was helium and the flow rate was $3.3 \mathrm{ml} \mathrm{min}-1$. The temperature was programmed at $75^{\circ} \mathrm{C}$ for 4 min then increased at $20^{\circ} \mathrm{C} \mathrm{min}^{-1}$ to $180^{\circ} \mathrm{C}$, followed by an increase of $2^{\circ} \mathrm{C} \mathrm{min}$ to $230^{\circ} \mathrm{C}$ and held for $8 \mathrm{~min}$. One $\mathrm{ml}$ of sample was injected onto the column. The temperatures of the injector and detector were $250^{\circ} \mathrm{C}$ and $220^{\circ} \mathrm{C}$, respectively. Peaks were identified by comparing their retention times with individual reference standard fatty acids (Nu-Chek-Prep, Elysian, MN).

\section{Statistical analysis}

To examine the difference between two diets, the t-test of two independent samples was performed. The $\mathrm{P}$ value of less than 0.05 was taken as statistical significance.

\section{RESULTS AND DISCUSSION}

\section{Growth performance}

There were no differences in dry matter (DM) intakes of concentrate and maize stover between maize group and wheat group $(\mathrm{P}>0.05)$, and the final body weight and body weight gain of goats in maize group were greater than those of goats in wheat group $(\mathrm{P}<0.05)$ (Table 2$)$.

The results of this study indicate that there was a difference in growth performance of goats between two diets based on maize and wheat, respectively. Previous studies have investigated the effects of the physical form of starter feed (Abdelgadir and Morrill, 1995; Beharka et al.,1998), type and level of hay, and grain processing on feed consumption, growth performance, and ruminal 
Table 2. Effects of starch sources on intakes and growth performances of goats

\begin{tabular}{|c|c|c|c|c|}
\hline \multirow{2}{*}{ Indices } & \multicolumn{2}{|c|}{ Starch sources } & \multirow{2}{*}{ SEM $^{1}$} & \multirow{2}{*}{$\mathrm{P}$} \\
\hline & wheat & maize & & \\
\hline Concentrate intake, $\mathrm{g} \mathrm{d}^{-1}$ & 190 & 191 & 1.6 & 0.427 \\
\hline Maize stover intake, $\mathrm{g} \mathrm{d}^{-1}$ & 214 & 218 & 1.7 & 0.128 \\
\hline Initial body weight, kg & 10.9 & 11.0 & 0.17 & 0.427 \\
\hline Final body weight, kg & $17.4^{\mathrm{b}}$ & $18.2^{\mathrm{a}}$ & 0.10 & 0.002 \\
\hline Body weight gain, $\mathrm{g} \mathrm{d}^{-1}$ & $72.2^{\mathrm{b}}$ & $80.0^{\mathrm{a}}$ & 2.4 & 0.024 \\
\hline
\end{tabular}

a,b means in the same row not bearing a common superscript letter differ significantly $(\mathrm{P}<0.05)$

${ }^{1} \mathrm{SEM}$ - the pooled standard error of means

development of ruminants (Coverdale et al., 2004; Lesmeister et al., 2004; Suárez et al., 2007). A greater growth rate for the lambs given maize as opposed to wheat was reported by Ørskov et al. (1974a). The body weight at post-weaning was greatest in calves fed a maize diet followed by those fed a wheat diet and then in those on barley and oat diets, with the differences being ascribed to differences between the cereal sources in rumen starch degradability (Khan et al., 2007). McEwen et al. (2007) reported that maize-fed steers grew faster than those fed barley and suggested that differences in gain due to grain source may be due to the higher net energy values of maize vs barley. Also Tiffany and Spears (2005) attributed greater gains and better feed conversion for maize- vs barley-fed steers to lower ME in barley diets due to higher NDF concentrations. It is well known that complicated interrelationships between starch and protein affected ruminal fermentation products (Ørskov, 1975), microbial synthesis (Hoover and Stokes, 1991), whole-body $\mathrm{N}$ metabolism, and milk yield and composition in ruminants (Khan et al., 2007). Starch digested in the small intestine can produce up to $42 \%$ more energy than fermentation because of a more efficient use of digestive end products: glucose vs volatile fatty acid (Owens et al., 1998). The site of starch digestion along the gastrointestinal tract affects performance and feed efficiency in cattle (Swan et al., 2006). The soluble starch (\% total starch) of maize and wheat was $26 \%$ and $68 \%$, respectively (Mills et al., 1999). Therefore, in the present study, the higher body weight gain in maize group may be ascribed to the differences in the characteristics of starch degraded in rumen between the diet based on maize or on wheat.

\section{Meat colour}

The results of slaughter performance are presented in Table 3. The carcass weight of goats fed the diet based on maize was greater than that of goats fed the diets based on wheat $(\mathrm{P}<0.05)$. There were no differencs in $\mathrm{L}^{*}$, $\mathrm{a}^{*}$ and $\mathrm{b}^{*}$ of Rectus abdominis and caudal fat of goats between two diets.( $\mathrm{P}>0.05)$. 
Table 3. Effects of starch sources on slaughter performance of goats

\begin{tabular}{|c|c|c|c|c|}
\hline \multirow{2}{*}{ Indices } & \multicolumn{2}{|c|}{ Starch sources } & \multirow{2}{*}{$\mathrm{SEM}^{1}$} & \multirow{2}{*}{$\mathrm{P}$} \\
\hline & wheat & maize & & \\
\hline Carcass weight, kg & $9.42^{\mathrm{b}}$ & $9.97^{\mathrm{a}}$ & 0.15 & 0.046 \\
\hline L* Rectus abdominis & 48.1 & 47.1 & 1.20 & 0.556 \\
\hline a* Rectus abdominis & 18.7 & 18.6 & 0.47 & 0.815 \\
\hline b* Rectus abdominis & 12.1 & 12.4 & 0.28 & 0.613 \\
\hline L* caudal fat & 67.5 & 68.1 & 1.41 & 0.745 \\
\hline a* caudal fat & 6.86 & 6.75 & 0.16 & 0.647 \\
\hline b* caudal fat & 6.24 & 6.38 & 0.15 & 0.528 \\
\hline
\end{tabular}

a,b means in the same row not bearing a common superscript letter differ significantly $(\mathrm{P}<0.05)$

${ }^{1} \mathrm{SEM}$ - the pooled standard error of means; ${ }^{2} \mathrm{~L} *$ lightness $(0=$ black, $100=$ white $)$, a* redness (positive values $=$ red, negative values $=$ green), $\mathrm{b}^{*}$ yellowness $($ positive values $=$ yellow, negative values $=$ blue $)$

The results of $\mathrm{L}^{*}, \mathrm{a}^{*}$ and $\mathrm{b} *$ in present study indicate that starch sources had no effect on the colour profiles of Rectus abdominis and caudal fat. However, previous studies have found that different rumen starch degradability would cause differences in meat colour. Starch as an energy source for veal calves resulted in a higher pigment content in the meat than lipids, the explanation being a better absorption of iron in the small intestine due to a lower $\mathrm{pH}$ in the starch-fed calves (Valin et al., 1978). A lower rumen starch degradability of diets caused a higher pigment content in the meat of finishing bulls, the argument being that the different meat colour may be due to an effect on the pigment concentration (Fiems et al., 1999).

\section{Physical and chemical characteristics of Longissimus dorsi muscle}

The marbling score of Longissimus dorsi muscle in wheat group was grater than that of in maize group, and there were no differences in other parameters of physical and chemical characteristics of Longissimus dorsi muscle determined in this study between maize group and wheat group $(\mathrm{P}>0.05)$ (Table 4).

Table 4. Effects of starch sources on physical and chemical characteristics of Longissimus dorsi muscle of goats

\begin{tabular}{|c|c|c|c|c|}
\hline \multirow{2}{*}{ Indices } & \multicolumn{2}{|c|}{ Starch sources } & \multirow{2}{*}{ SEM $^{1}$} & \multirow{2}{*}{$\mathrm{P}$} \\
\hline & wheat & maize & & \\
\hline Longissimus dorsi area, $\mathrm{cm}^{2}$ & 9.30 & 9.17 & 0.24 & 0.723 \\
\hline Marbling score & $3.10^{\mathrm{a}}$ & $2.70^{\mathrm{b}}$ & 0.05 & 0.002 \\
\hline $\mathrm{pH}$, at 40 min post-mortem & 6.77 & 7.00 & 0.16 & 0.380 \\
\hline $\mathrm{pH}$, at $24 \mathrm{~h}$ post-mortem & 5.78 & 6.12 & 0.15 & 0.149 \\
\hline Moisture, \% & 77.1 & 77.4 & 0.24 & 0.268 \\
\hline Crude fat, \% & 1.67 & 1.52 & 0.23 & 0.328 \\
\hline Protein, \% & 19.8 & 19.6 & 0.47 & 0.898 \\
\hline Ash, \% & 1.43 & 1.38 & 0.03 & 0.272 \\
\hline
\end{tabular}

${ }^{\mathrm{a}, \mathrm{b}}$ means in the same row not bearing a common superscript letter differ significantly $(\mathrm{P}<0.05)$

${ }^{1} \mathrm{SEM}$ - the pooled standard error of means 
Some physical and chemical characteristics of Longissimus dorsi muscle may be related to the proportion of degradable starch in rumen. Post ruminal starch digestion occurs mainly in the small intestine and results in free glucose that is available for absorption by all adipose tissue depots (Owens et al.,1986; Gilbert et al., 2003; Schoonmaker et al., 2003). However, apart from marbling score, the proportions of moisture, protein and fat in the Longissimus dorsi muscle were not significantly different in the present study. Our results are in agreement with several studies over the past decade (Miller et al., 1996; Boles et al., 2005; Koenig and Beauchemin, 2005; McEwen et al., 2007), which found no differences in WarnerBratzler shear force measurements, and taste panel evaluations for tenderness, juiciness, and flavour when comparing beef from cattle finished on maize vs barley. Fiems et al. (1999) also found that the proportion of rumen degradable starch in the diet had no effects on the proportions of moisture, protein and fat in the Longissimus thoracis muscle. The differences in the physical and chemical characteristics of Longissimus dorsi muscle of ruminant as affected by different starch sources need further study.

\section{Fatty acid composition of Longissimus dorsi muscle}

The C14:0 proportion of Longissimus dorsi muscle in the wheat group was greater than that of goats in the maize group $(\mathrm{P}<0.05)$, however, the $\mathrm{C} 18: 3$ proportion of Longissimus dorsi muscle in wheat group was lower than that of goats in maize group $(\mathrm{P}<0.05)$. The other parameters of fatty acid composition of Longissimus dorsi muscle determined in this study between the two groups were not significantly different $(\mathrm{P}>0.05)$ (Table 5).

Table 5. Effects of starch sources on fatty acid composition of Longissimus dorsi muscle fatty acid methyl esters of goats, g/100 g

\begin{tabular}{|c|c|c|c|c|}
\hline \multirow{2}{*}{ Fatty acid } & \multicolumn{2}{|c|}{ Starch sources } & \multirow{2}{*}{ SEM $^{1}$} & \multirow{2}{*}{$\mathrm{P}$} \\
\hline & wheat & maize & & \\
\hline$\overline{\mathrm{C} 14: 0}$ & $5.32^{\mathrm{a}}$ & $4.30^{\mathrm{b}}$ & 0.14 & 0.001 \\
\hline C16:0 & 22.8 & 22.7 & 1.7 & 0.987 \\
\hline C18:0 & 12.7 & 12.8 & 0.19 & 0.697 \\
\hline C18:1 & 37.5 & 38.1 & 0.64 & 0.522 \\
\hline C18:2 & 13.3 & 13.4 & 0.58 & 0.870 \\
\hline $\mathrm{C} 18: 3$ & $1.53^{\mathrm{b}}$ & $2.14^{\mathrm{a}}$ & 0.07 & $<0.001$ \\
\hline $\mathrm{C} 20: 4$ & 6.82 & 6.51 & 0.13 & 0.133 \\
\hline Saturated & 39.6 & 38.2 & 1.31 & 0.469 \\
\hline Monounsaturated & 31.2 & 31.7 & 0.56 & 0.541 \\
\hline Polyunsaturated & 29.2 & 30.1 & 0.76 & 0.425 \\
\hline$\underline{\mathrm{P} / \mathrm{S}}$ & 0.93 & 0.95 & 0.01 & 0.309 \\
\hline
\end{tabular}

a,b means in the same row not bearing a common superscript letter differ significantly $(\mathrm{P}<0.05)$

${ }^{1} \mathrm{SEM}$ - the pooled standard error of means 
The results indicate that there was difference in fatty acids composition of the Longissimus dorsi muscle between maize group and wheat group. Feeding systems can play a significant role in improving meat dietetic quality, as the changes in fatty acid composition of body fats and lipid stability during storage are primarily linked to the respective fatty acid contents in the pastures or concentrate and hay (Popova, 2007). Despite rumen hydrogenation, it has been shown that pasture feeding increases the concentration of meat n-3 PUFA, compared with grain feeding (Ørskov et al., 1974b; Aurousseau et al., 2004; Gatellier et al., 2005). Bas and Morand-Fehr (2000) showed that the carcass of lambs fed a diet based on maize contained more odd-numbered fatty acids than the lambs given wheat. Gill et al. (2008) reported that a diet based on maize or sorghum distiller grains increased steak n-6 fatty acid and linoleic acid concentrations of beef compared with the diet based on a steam-flaked maize. In a previous study with lambs it was found that lipids in different fat depots (endogenous and subcutaneous) of grazing ruminants contained relatively more linolenic acid, with a lower C18:2n-6/ C18:3n-3 ratio, than the concentrate fed animals (Banskalieva et al., 2005). The fatty acid compositions of the Longissimus thoracis muscle in finishing bulls among diets with different starch level or different rumen degradable starch were different, especially with regard to C14:0 and C18:0 (Fiems et al., 1999). To our knowledge, scientific studies carried out to investigate the effects of starch sources on fatty acid composition of muscle or adipose tissues of meat of ruminants are limited. Therefore, the results of this study need further study.

\section{CONCLUSIONS}

In conclusion, the present study has shown that the goats fed the diet based on maize achieved a greater growth performance and a lower proportion of $\mathrm{C} 18: 3$ fatty acids and marbling score of Longissimus dorsi muscle when compared with those of goats fed the diet based on wheat. Therefore, in terms of growth performance, maize is preferable to wheat as a starch source for meat ruminants. In contrast, wheat is the preferable starch source for the fatty acid content of the meat. In practice the application of these scientific findings in the formulation of diets is likely to be influenced by the relative cost of the two starch sources.

\section{REFERENCES}

Abdelgadir I.E.O., Morrill J.L., 1995. Effect of processing sorghum grain on dairy calf performance. J. Dairy Sci. 78, 2040-2046

AOAC, 1995. Association of Official Analytical Chemists, Official Methods of Analysis. 16 $6^{\text {th }}$ Edition. Washington, DC 
Aurousseau B., Bauchart D., Calichon E., Micol D.,Priolo A., 2004. Effect of grass or concentrate feeding systems and rate of growth on triglyceride and phospholipid and their fatty acids in the M. longissimus thoracis of lambs. Meat Sci. 66, 531-541

Banskalieva V., Marinova P., Monin G., Popova T., Ignatova M., 2005. Manipulating of the carcass and meat quality in lamb meat producing for the European Market II. Fatty acid composition of fat depots of lambs grown under two different production systems. Bulg. J. Agr. Sci. 11, 603-610

Bas P., Morand-Fehr P., 2000. Effect of nutritional factors on fatty acid composition of lamb fat deposits. Livest. Prod. Sci. 64, 61-79

Beharka A.A., Nagaraja T.G., Morrill J.L., Kennedy G.A., Klemm R.D., 1998. Effects of form of the diet on anatomical, microbial, and fermentative development of the rumen of neonatal. calves. J. Dairy Sci. 81, 1946-1955

Boles J.A., Bowman J.G.P., Boss D.L., Surber L.M.M., 2005. Meat color stability affected by barley variety in finishing diet to beef steers. Meat Sci. 70, 633-638

Burke J.M., Apple J.K., 2007. Growth performance and carcass traits of forage-fed hair sheep wethers. Small Ruminant Res. 67, 264-270

CIE, 1986. Commission International d'Eclairage. Colorimetry. $2^{\text {nd }}$ Edition. Publication CIE 15.2, Vienna

Coverdale J.A., Tyler H.D., Quigley J.D., Brumm J.A., 2004. Effect of various levels of forage and form of diet on rumen development and growth in calves. J. Dairy Sci. 87, 2554-2562

Fiems L.O., Campeneere S.D., Cottyn B.G., Vanacker J.M., Heer B.G.J.D., Boucqué C.H.V., 1999. Effect of amount and degradability of dietary starch on animal performance and meat quality in beef bulls. J. Anim. Physiol. Anim. Nutr. 82, 217-226

Folch J., Lees M., Sloan-Stanley G.N., 1957. A simple method for the isolation and purification of total lipids from animal tissues. J. Biol. Chem. 226, 497-509

Gatellier P., Mercier Y., Juin H., Renerre M., 2005. Effect of finishing mode (pasture or mixed diet) on lipid composition, color stability and lipid oxidation in meat from Charolais cattle. Meat Sci. $69,175-186$

Gilbert C.D., Lunt D.K., Miller R.K., Smith S.B., 2003. Carcass, sensory, and adipose tissue traits of Brangus steers fed casein-formaldehyde-protected starch and/or canola lipid. J. Anim. Sci. $81,2457-2468$

Gill R.K., VanOverbeke D.L., Depenbusch B., Drouillard J.S., Dicostanzo A., 2008. Impact of beef cattle diets containing corn or sorghum distillers grains on beef color, fatty acid profiles, and sensory attributes. J. Anim. Sci. 86, 923-935

Hoover W.H., Stokes S.R., 1991. Balancing carbohydrates and protein for optimum rumen microbial yield. J. Dairy Sci. 74, 3630-3644

Huuskonen A., 2009. The effect of cereal type (barley versus oats) and rapeseed meal supplementation on the performance of growing and finishing dairy bulls offered grass silage-based diets. Livest. Sci. 122, 53-62

ISO, 1978. Animal Feeding Stuffs - Determination of Crude Ash. ISO 5984 International Organization for Standardization. Geneva (Switzerland)

Khan M.A., Lee H.J., Lee W.S., Kim H.S., Kim S.B., Ki K.S., Park S.J., Ha J.K., Choi Y.J., 2007. Starch source evaluation in calf starter: I. Feed consumption, body weight gain, structural growth, and blood metabolites in Holstein calves. J. Dairy Sci. 90, 5259-5268

Koenig K.M., Beauchemin K.A., 2005. Barley- versus protein-supplemented corn-based diets for feedlot cattle evaluated using the NRC and CNCPS beef models. Can. J. Anim. Sci. 85, $377-$ 388

Lesmeister K.E., Tozer P.R., Heinrichs A.J., 2004. Development and analysis of a rumen tissue sampling procedure. J. Dairy Sci. 87, 1336-1344 
Li Y., Watkins B.A., 1998. Conjugated linoleic acids alter bone fatty acid composition and reduce ex vivo prostaglandin E2 biosynthesis in rats fed n-6 or n-3 fatty acids. Lipids 33, 417-425

Lu D.X., Zhang P.Y., Wang X.M., 1996. Modern Method and Technology on Ruminant Nutrition Research. Chinese Agriculture Press, Beijing (China)

McEwen P.L., Mandell I.B., Brien G.,Campbell C.P., 2007. Effects of grain source, silage level, and slaughter weight endpoint on growth performance, carcass characteristics, and meat quality in Angus and Charolais steers. Can. J. Anim. Sci. 87, 167-180

Miller R.K., Rockwell L.C., Lunt D.K., Carstens G.E., 1996. Determination of the flavor attributes of cooked beef from cross-bred Angus steers fed corn- or barley-based diets. Meat Sci. 44, 235-243

Mills J.A.N., France J., Dijkstra J., 1999. A review of starch digestion in the lactating dairy cow and proposals for a mechanistic model: 1 . Dietary starch characterization and ruminal starch digestion. J. Anim. Feed Sci. 8, 291-340

NRC, 2001. Nutrient Requirements of Dairy Cattle. $17^{\text {th }}$ revised Edition. National Academy Press. Washington, DC

Ørskov E.R., 1975. Manipulating of rumen fermentation for maximum food utilization. World Rev. Nutr. Diet. 22, 152-182

Øskov E.R., Fraser C., Gordon J.G., 1974b. Effect of processing of cereals on rumen fermentation, digestibility, rumination time, and firmness of subcutaneous fat in lambs. Brit. J. Nutr. 32, 5969

Øskov E.R., Fraser C., McHattie I., 1974a. Cereal processing and food utilization by sheep 2. A note on the effect of feeding unprocessed barley, maize, oats and wheat on food utilization by early weaned lambs. Anim. Prod. 18, 85-88

Owens F.N., Secrist D.S., Hill W.J., Gill D.R., 1998. Acidosis in cattle: A review. J. Anim. Sci. 76, 275-286

Owens F.N., Zinn R.A., Kim Y.K., 1986. Limits to starch digestion in the ruminant small intestine. J. Anim. Sci. 63, 1634-1648

Popova T., 2007. Effect of the rearing system on the fatty acid composition and oxidative stability of the M. longissimus lumborum and M. semimembranosus in lambs. Small Ruminant Res. $71,150-157$

Rhoades R.D., Sawyer J.E., Chung K.Y., Schell M.L., Lunt D.K., Smith S.B., 2007. Effect of dietary energy source on in vitro substrate utilization and insulin sensitivity of muscle and adipose tissues of Angus and Wagyu steers. J. Anim. Sci. 85, 1719-1726

Schoonmaker J.P., Cecava M.J., Faulkner D.B., Fluharty F.L., Zerby H.N., Loerch S.C., 2003. Effect of source of energy and rate of growth on performance, carcass characteristics, ruminal fermentation, and serum glucose and insulin of early-weaned steers. J. Anim. Sci. 81, 843-855

Suárez B.J., Van Reenen C.G., Stockhofe N., Dijkstra J., Gerrits W.J., 2007. Effect of roughage source and roughage to concentrate ratio on animal performance and rumen development in veal calves. J. Dairy Sci. 90, 2390-2403

Sun Z.H., Hu Y., Liu S.M.,Tang S.X., Han X.F., Zhou C.S., Wang M., He Z.X., Tan Z.L., 2011. Net nutrient flux in visceral tissues of goats fed diets based on maize or wheat. J. Anim. Feed Sci. 20, 26-35

Svihus B., Uhlen A.K., Harstad O.M., 2005. Effect of starch granule structure, associated components and processing on nutritive value of cereal starch: A review. Anim. Feed Sci. Tech. 122, 303-320

Swan C.G., Bowman J.G.P., Martin J.M., Giroux M.J., 2006. Increased puroindoline levels slow ruminal digestion of wheat (Triticum aestivum L.) starch by cattle. J. Anim. Sci. 84, 641-650 
Szabó C., Jansman A.J.M., Babinszky L., Kanis E., Verstegen M.W., 2001. Effect of dietary protein source and lysine: DE ratio on growth performance, meat quality, and body composition of growing-finishing pigs. J. Anim. Sci. 79, 2857-2865

Tagari H., Webb K., Theurer B. et al., 2004. Portal drained visceral flux, hepatic metabolism, and mammary uptake of free and peptide-bound amino acids and milk amino acid output in dairy cows fed diets containing corn grain steam flaked at 360 or steam rolled at $490 \mathrm{~g} / \mathrm{L}$. J. Dairy Sci. $87,413-430$

Taniguchi K., Huntington G., Glenn B.P., 1995. Net nutrient flux by visceral tissues of beef steers given abomasal and ruminal infusions of casein and starch. J. Anim. Sci. 73, 236-249

Tiffany M.E., Spears J.W., 2005. Differential responses to dietary cobalt in finishing steers fed cornversus barley-based diets. J. Anim. Sci. 83, 2580-2589

Valin C., Renerre M., Touraille C.,Koop J., Sornay J., 1978. Effects of the nature of energy in food and use of anabolic agents on the quality of veal. Ann. Nutr. Aliment. 32, 857-868

Wiegand B.R., Sparks J.C., Parrish F.C., Zimmerman D.R., 2002. Duration of feeding conjugated linoleic acid influences growth performance,carcass traits, and meat quality of finishing barrows. J. Anim. Sci. 80, 637-643

Zhang H.F., Zhang Z.Y., 1998. Animal Nutrition Parameters and Feeding Standard. Chinese Agriculture Press. Beijing (China) 